\title{
Abundance and Diversity of Soil Mites (Acari: Gamasida \& Oribatida) in Mango Orchards in Ismailia Region, Egypt
}

\author{
H. M. El-Sharabasy \\ Plant Protection Dept., Faculty of Agric., Suez Canal Univ., Ismailia, Egypt \\ (Received: June 23, 2010)
}

\begin{abstract}
The relative abundance of gamasid and oribatid mites inhabiting soil and litter in mango orchards was investigated in Ismailia region, Egypt. Soil and litter samples were collected from August 2008 to July 2009. Totally, 6057 individuals of gamasid and oribatid mites were found in the collected soil and litter samples. The collected mites belong to 34 mite species and 18 families. Gamasida was represented by 20 species of 2212 individuals, while Oribatida was represented by 14 species of 3845 individuals. Gamasid mites were generally dominated by Parasitus zaheri Hafez and Nasr in the soil samples, while in the litter, seven species were influent and the others were recedent. Oribatida comprised $63.48 \%$ of total mites collected and dominated by six species in both soil and litter. The highest population density of soil mites was recorded in winter months compared with summer months. Biotic and abiotic factors affecting abundance of soil mites were discussed.
\end{abstract}

Key Words: Soil mites, Gamasida, Oribatida, Abundance, Diversity, Seasonal variations, Ismailia.

\section{INTRODUCTION}

Microarthropods living in litter and upper strata of the soil are an important component of the ecosystem, because of their relevant role in organic matter decomposition, mineralization, nutrient cycling and soil formation (Seastedt, 1984; Koehler, 1997; Parisi, et al., 2005; Schneider et al., 2007). Mites are major participants in soil food web. Some species feed directly upon decomposing plant materials; while others are fungivores. Other species are predators on small arthropods or their eggs and nematodes. Many species seem to be omnivorous.

Gamasid mites live in a wide range of terrestrial ecosystems under very different environmental conditions. Most are top predators and occupy a central position in the soil food web (Koehler, 1999). Thus, communities have significant role in regulating decomposition and nutrient cycling since they influence population growth of other organisms (Koehler, 1999). Soil gamasida communities are sensitive to changes in management practices and the type of land use is an especially critical parameter (Ruf and Beck, 2005).

Oribatid mites are usually the most abundant and diverse arthropods in soil. Its importance in ecosystem energy and nutrient dynamics is mostly indirect, and lies in its relationships with decomposer microorganisms (Seastedt, 1984). The density of soil mites is also considered as indicator of soil condition and quality (Usher, 1971). Population abundance of soil mites in scil vary in relation to various envirommental ficars i.e.; temperature, moisture, organic matter and nutrient availability (Hansen \& Coleman 1998 ,
Several studies have been conducted to study the distribution and abundance of mites inhabiting soil and debris at different locations in Egypt (El-Kifl et al., 1974; Zaher and Mohamed 1980; Hassan et al., 1986; Zaki, 1992 and Kandeel, 1993). The main objective of this study is to work composition, density and seasonal changes of soil and litter mites (Gamasida and Oribatida) found in mango orchards in Ismailia region.

\section{MATERIALS AND METHODS}

\section{Site description and sampling:}

The present study was carried out on the experimental farm of Faculty of Agriculture, Suez Canal University, Ismailia Governorate. Ismailia is characterized by aridity with long hot rainless summer, mild winter and low amount of rainfall $(50 \mathrm{~mm})$. Three random samples of the top soil layer $(0-20 \mathrm{~cm})$ and litter layer in mango orchards, Mangifera indica $\mathrm{L}$. were taken using a core from August 2008 to July 2009. Sampling was done four times monthly and a total of 720 samples were collected. Mites were extracted from the soil and litter samples by using modified Tullgren Funnel. Identification was carried out according to Karg, 1971 and Zaher, 1986). The specimens of each mite species were deposited in the mite collection of Department of Plant Protection, Faculty of Agriculture, Suez Canal University. pH, organic matter content, temperature and moisture content $(\%$ of dry weight) of soil and litter samples were recorded.

\section{Data analysis:}

The community structure of soil mites was analyzed using abundance and species number. For 
the quantitative categorization of the mites found, the criteria Dominance (D) were used, as suggested by (Kang et al., 2001). 'Dominance' indicates the percentage of individuals of a given species compared to the individuals of all species found. Thus, a given species can be classified as 'Dominant' $(>5 \%)$, 'Influent' ( $2-5 \%)$, and 'Resident' $(<2 \%)$ of the community structure of soil arthropods. Total number of individuals, total number of species (species richness) and Shannon-Wiener index $\left(\mathrm{H}^{\prime}\right)$ and the evenness $\left(J^{\prime}\right)$ Magurran, (1988) were assessed. Statistical analysis were carried out using the SAS package, and the Duncan multiple range test was used to compare the means of soil mite populations.

\section{RESULTS AND DISCUSSION}

\section{Soil and litter characteristics:}

Data of soil and litter $\mathrm{pH}$, organic matter content and temperature are presented in table (1). The type of soil in the study area was sandy loam. The average value of $\mathrm{pH}$ ranged from 5.1 in litter to 7.7 in the soil. The mean values of total organic matter percentage were significantly higher in litter compared with soil. Soil temperature was relatively higher in litter. Organic matter content is a source for nutrient elements in the soil. It has appreciable influence on many soil properties, for its significance in maintenance of soil fertility. Litter of substrate can affect the rate of decomposition and the populations and community dynamics of soil fauna, partially explaining the increase in abundance of Gamasida and Oribatida.

Table (1): Means of general characteristics of soil and litter of the studied area.

\begin{tabular}{lcccc}
\hline Biotope & $\mathrm{pH}$ & $\begin{array}{c}\text { Organic } \\
\text { matter } \%\end{array}$ & $\begin{array}{c}\text { Temperature } \\
{ }^{\circ} \mathrm{C}\end{array}$ & $\begin{array}{c}\text { Moisture } \\
\%\end{array}$ \\
\hline Soil & 7.7 & 0.87 & 19.8 & 3.1 \\
\hline Litter & 5.1 & 46.2 & 27.2 & 15.7 \\
\hline
\end{tabular}

Abundance and diversity:

A total of 6057 individuals of soil mites (Gamasida \& Oribatida) were extracted from the litter and soil samples (Tables 2 and 3). The collected individuals belonged to 34 mite species. There was a significantly higher number of soil mites $(p<0.05)$ in litter samples than soil.

Gamasida: A total of 2212 Gamasida specimens were noted in the samples. 312 in litter and 900 in soil. Laelapidae was represented by the largest number of species (5 spp.) and individuals in both soil and litter (202 and 244 individuals, respectively). The Family Parasitidae dominated by Parasitus zaheri $\mathrm{Hafez}$ and Nasr in the soil samples only $(D=16.11 \%)$, followed by Rhodacarus rosesus (12.22\%) (Family Rhodacaridae). The families Ascidae, Parasitidae and Macrochelidae were represented by more than one species (4, 2 and 3 species, respectively). However, Ascidae (104 individuals), Parasitidae (165) and Macrochelidae (113) were the families with the most numerous individuals (Table 2). In all samples the density of gamasid mites in litter was higher than in the soil $(\mathrm{p}<0.05)$. Species diversity index $\left(\mathrm{H}^{\prime}\right)$ for gamasid mites were 2.64 and 2.84 at soil and litter, respectively and species evenness $\left(J^{\prime}\right)$ was 0.88 and 0.95 , respectively (Table 2).

Oribatida: The suborder Oribatida comprised 63.48 $\%$ of total mites collected. A total of 3845 individuals were obtained from the sampling areas. 1412 individuals from soil and 2433 individuals from litter. Oribatid mites were dominated by Galumna tarsipennata (Grandjean) (D = $19.83 \%)$, Oppiella nova (Oudemans) $(\mathrm{D}=13.46 \%)$, Oppia sticta Popp $(\mathrm{D}=8.29 \%)$, O. bayomi Shereef and Zaher $(\mathrm{D}=10.34 \%)$, and $O$. concolor Koch $(\mathrm{D}=$ $8.49 \%$ ) in the soil. On the other hand, Oppiella nova was the most dominant species in the litter $(\mathrm{D}=$ $13.33 \%$ ) (Table 3 ).

The Oppiidae was a family represented by the largest number of species (4 species). It is also resulted in the largest number of individuals collected (1639) of which 573 from soil and 1066 from litter. This may be due to the increase of organic matter content in litter and supported by the findings of Urhan et al., (2008) who reported that cryptostigmatid mites mostly dominate in soils that are rich in organic matter. Soil temperature exhibited strong negative correlation with the mite population. Such observations were made by El-Kifl et al., (1974) and Zaher and Mohamed (1980).

The Oribatulidae (488 individuals), Galumnidae (474 individuals), Phthiracaridae (348 individuals) and Lohmannidae (320 individuals) were the families with numerous individuals (Table 3 ). Ctenacarus araneola (Grandjean) and Aphilacarus acarinus (Berlese) were classified as a resident species in both soil and litter (Table 3).

Oribatid mites density in the litter is nearly twice times as that in soil. Species diversity index $\left(\mathrm{H}^{\prime}\right)$ of oribatid mites was higher at litter (2.49) than soil (2.37), and species evenness ( $\left.\mathrm{J}^{\prime}\right)$ was 0.89 and 0.94 at soil and litter, respectively (Table 3 ). 
Table (2): List of gamasid mites in Ismailia region during the study period.

\begin{tabular}{|c|c|c|c|c|}
\hline \multirow{2}{*}{ Species } & \multicolumn{2}{|c|}{ Abundance } & \multicolumn{2}{|c|}{ Dominance $(\%)$} \\
\hline & Soil & Litter & Soil & Litter \\
\hline \multicolumn{5}{|l|}{ Family: Ascidae } \\
\hline Lasioseius aegypticus Afifi & 30 & 35 & 3.33 & 2.67 \\
\hline Protogamasellus denticus Nasr & 24 & 40 & 2.67 & 3.05 \\
\hline Blattisocieus keegani Fox & 21 & 51 & 2.33 & 3.89 \\
\hline Gamasellodes $s p$ & 29 & 38 & 3.22 & 2.89 \\
\hline \multicolumn{5}{|l|}{ Family: Rhodacaridae } \\
\hline Rhodacarus rosesus Oudemans & 110 & 172 & 12.22 & 13.11 \\
\hline \multicolumn{5}{|l|}{ Family: Phytoseiidae } \\
\hline Amblyseius cydnodactylon Shehata \& Zaher & 31 & 50 & 3.45 & 3.81 \\
\hline \multicolumn{5}{|l|}{ Family: Ologamasidae } \\
\hline Gamasiphis denticus Hafez \& Nasr & 41 & 58 & 4.56 & 4.42 \\
\hline \multicolumn{5}{|l|}{ Family: Uropodidae } \\
\hline Uroobovella (Fuscropoda) krantzi Zaher and Afifi & 86 & 111 & 9.55 & 8.46 \\
\hline Trichouropoda patavina (Canestrini) & 35 & 60 & 3.89 & 4.57 \\
\hline \multicolumn{5}{|l|}{ Family: Laelapidae } \\
\hline Laelaspis zaheri Shereef \& Soliman & 51 & 56 & 5.67 & 4.27 \\
\hline L. volgini shereef and Afifi & 37 & 43 & 4.11 & 3.27 \\
\hline Hypoaspis miles (Berlese) & 58 & 60 & 6.45 & 4.57 \\
\hline H. baloghi shereefand Afifi & 34 & 32 & 3.78 & 2.44 \\
\hline Androlaelaps casalis Berlese & 22 & 53 & 2.44 & 4.04 \\
\hline \multicolumn{5}{|l|}{ Family: Ameroseiidae } \\
\hline Amerosius aegypticus El-Badry, Nasr and Hafez & 13 & 47 & 1.44 & 3.58 \\
\hline \multicolumn{5}{|l|}{ Family: Parasitidae } \\
\hline Parasitus zaheri $\mathrm{Hafez}$ and Nasr & 145 & 147 & 16.11 & 11.2 \\
\hline Vulgarogamasus burchanensis (Oudemans) & 20 & 32 & 2.22 & 2.44 \\
\hline \multicolumn{5}{|l|}{ Family: Macrochelidae } \\
\hline Macrocheles solimani Hafez, El-Badry\&Nasr & 65 & 104 & 7.22 & 7.93 \\
\hline M. glober Muller & 38 & 60 & 4.22 & 4.57 \\
\hline M. muscaedomesticae (Scopoli) & 10 & 63 & 1.11 & 4.8 \\
\hline Total individuals & 900 & 1312 & & \\
\hline No of dominant species & & & 5 & 4 \\
\hline $\mathbf{H}^{\prime}$ & 2.64 & 2.84 & & \\
\hline $\mathbf{J}^{\prime}$ & 0.88 & 0.95 & & \\
\hline LSD 5\% & 82.1 & 125.3 & & \\
\hline
\end{tabular}

$\mathrm{H}^{\prime}=$ Shannon's diversity index, $J^{\prime}=$ Pielou's evenness index. 
Table (3): List of oribatid mites in Ismailia region during the study period.

\begin{tabular}{|c|c|c|c|c|}
\hline \multirow{2}{*}{ Species } & \multicolumn{2}{|c|}{ Abundance } & \multicolumn{2}{|c|}{ Dominance $(\%)$} \\
\hline & Soil & Litter & Soil & Litter \\
\hline \multicolumn{5}{|l|}{ Family: Galumnidae } \\
\hline Galumna tarsipennata (Grandjean) & 280 & 194 & 19.83 & 7.97 \\
\hline \multicolumn{5}{|l|}{ Family: Oribatulidae } \\
\hline Scheloribates zaheri Yousef \& Nasr & 53 & 213 & 3.75 & 8.75 \\
\hline Zygoribatula tritici El-Badry \& Nasr & 58 & 164 & 4.11 & 6.74 \\
\hline \multicolumn{5}{|l|}{ Family: Oppiidae } \\
\hline Oppiella nova (Oudemans) & 190 & 324 & 13.46 & 13.32 \\
\hline Oppia sticta Popp & 117 & 263 & 8.29 & 10.81 \\
\hline$O$. bayomi Shereef and Zaher & 146 & 283 & 10.34 & 11.63 \\
\hline O. concolor Koch & 120 & 196 & 8.49 & 8.05 \\
\hline \multicolumn{5}{|l|}{ Family: Epilohmanniidae } \\
\hline Epilohmannia cylindrical Berlese & 105 & 132 & 7.44 & 5.43 \\
\hline \multicolumn{5}{|l|}{ Family: Lohmannidae } \\
\hline Lohmannia egypticus El-Badry \& Nasr & 47 & 113 & 3.33 & 4.64 \\
\hline Papillacarus aciculatus Kunast & 38 & 122 & 2.69 & 5.01 \\
\hline \multicolumn{5}{|l|}{ Family: Cosmochthonidae } \\
\hline Cosmochthonius lanatus (Michael) & 25 & 86 & 1.77 & 3.53 \\
\hline \multicolumn{5}{|l|}{ Family: Ctenacaridae } \\
\hline Ctenacarus araneola (Grandjean) & 33 & 69 & 2.33 & 2.84 \\
\hline \multicolumn{5}{|l|}{ Family: Aphilacaridae } \\
\hline Aphilacarus acarinus (Berlese) & 28 & 58 & 1.98 & 2.38 \\
\hline \multicolumn{5}{|l|}{ Family: Phthiracaridae } \\
\hline Phthiracarus sp. & 172 & 216 & 12.18 & 8.89 \\
\hline Total individuals & 1412 & 2433 & & \\
\hline No of dominant species & & & 7 & 10 \\
\hline $\mathbf{H}^{\prime}$ & 2.37 & 2.49 & & \\
\hline $\mathbf{J}^{\prime}$ & 0.89 & 0.94 & & \\
\hline LSD $5 \%$ & 78.6 & 134.2 & & \\
\hline
\end{tabular}

$\mathrm{H}^{\prime}=$ Shannon's diversity index, $\mathrm{J}^{\prime}$ = Pielou's evenness index.

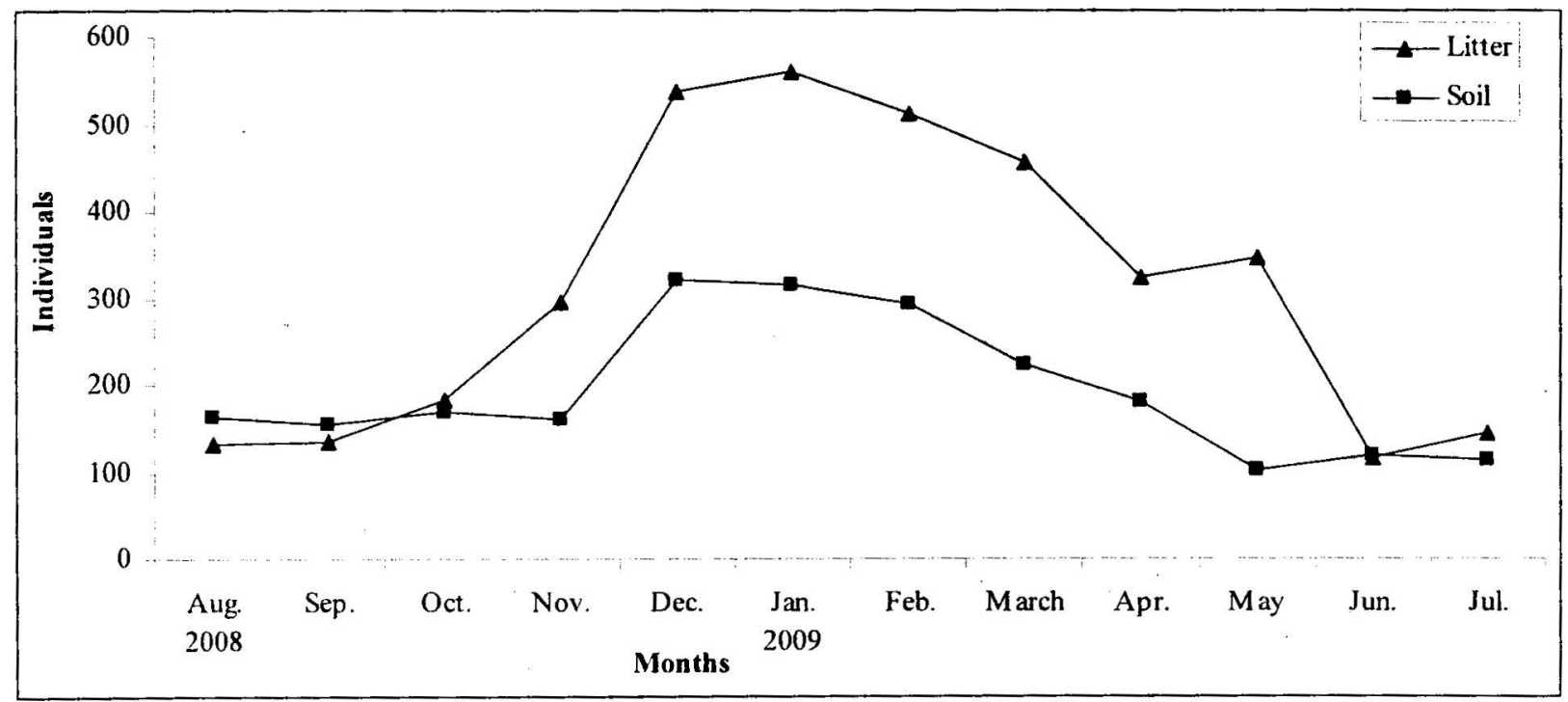

Fig. 1: Seasonal variations of total soil mites in soil and litter in Ismailia region 


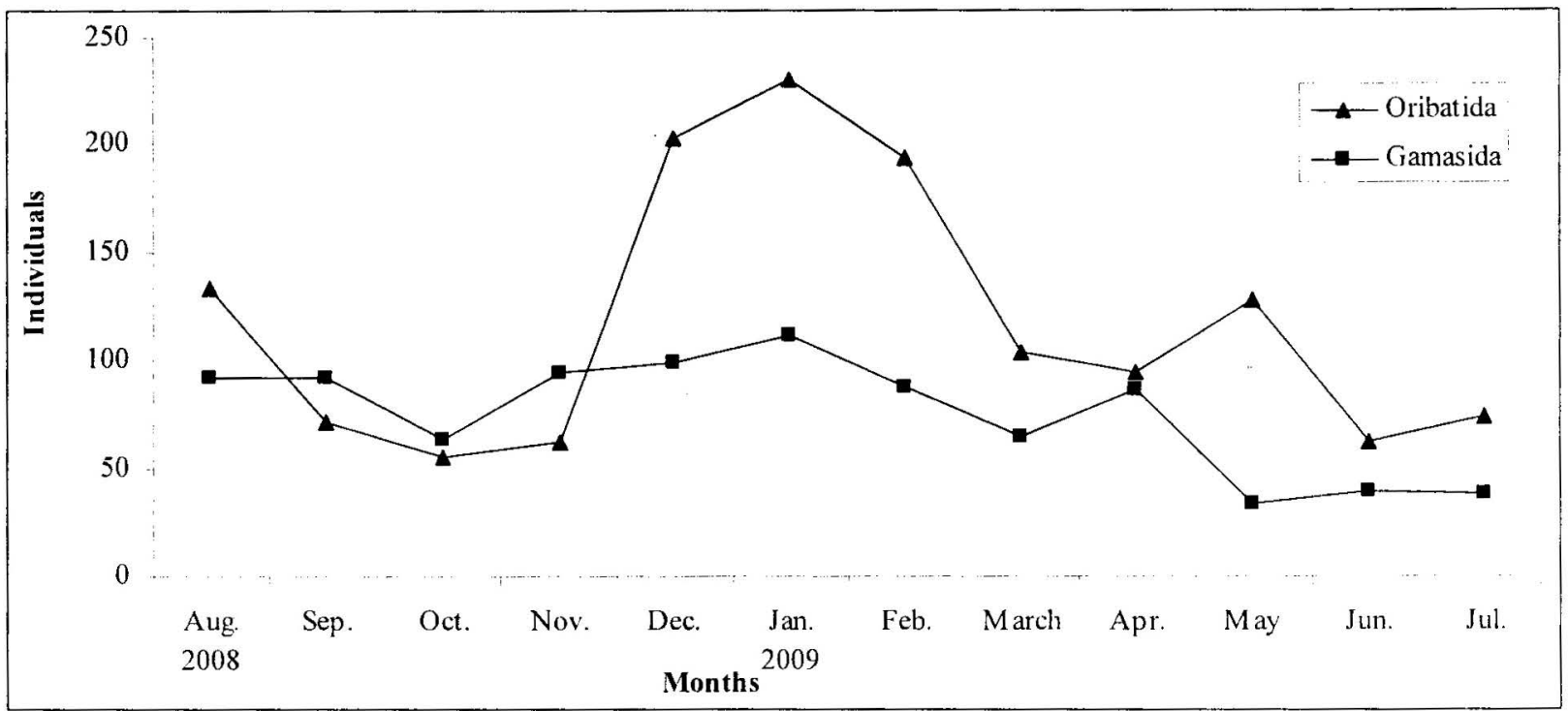

Fig.2: Density pattern of soil mites in the soil during the study period

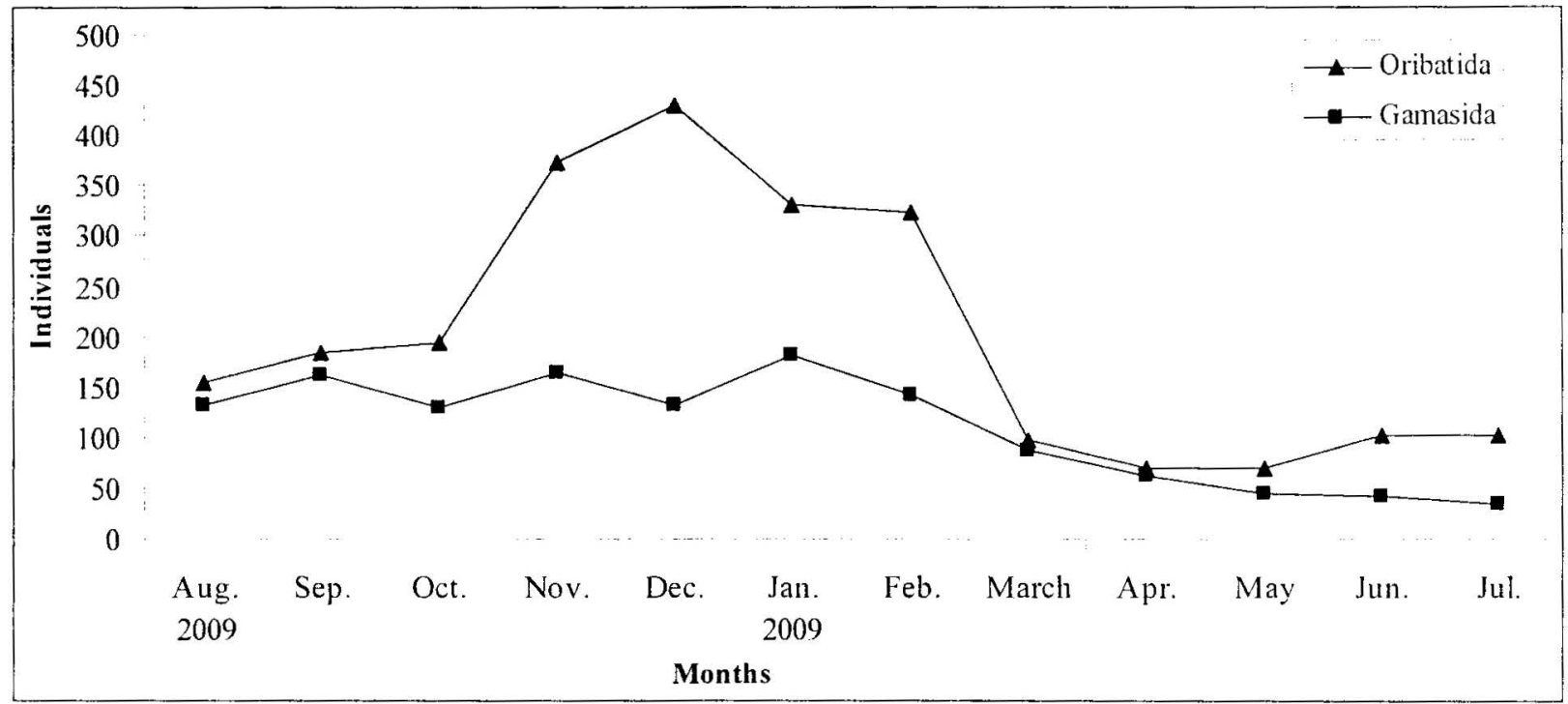

Fig.3: Density pattern of soil mites in litter during the study period

\section{Seasonal variation of population density:}

Fig. (1) illustrates the seasonal variations of gamasid and oribatid mites inhabiting soil and litter. Soil mites were more abundant throughout the year in litter than in soil. The highest population density was recorded in December - February in both litter and soil, while the lowest density was in May- July. El-Kifl et al., (1974) found oribatid mites tended to decrease during summer months. They found that the minimal means were noticed in June.

It is clear that gamasid individuals were less abundant compared to oribatids. The highest population of gamasida was recorded in January (Fig. 2). On the other hand, the lowest was recorded during summer months. High temperature and low water moisture seem to be unsuitable soil environmental factors resulting in decreasing the population of soil mites.

The oribatid mites were more abundant throughout the year in soil than in litter. Its population density was higher during November January compared to other months (Fig. 3). Its highest density was recorded in December and January in soil and litter, respectively. On the other hand, lowest density of oribatids was recorded in May and June in soil and litter. The distribution is affected by two factors which are classified into direct and indirect. The direct ones are the environmental factors (air. soil temperature, soil moisture and rainfall) and soil quality, while the indirect factors are those corresponding to choice of microhabitat, food and the relation between individuals (Zaki, 1992). 


\section{ACKNOWLEDGEMENTS}

The author is grateful to Dr Ahmed Ibrahim, Soil and Water Department, Faculty of Agriculture, Suez Canal University for soil and litter analysis.

\section{REFERENCES}

El-Kifl, A. H.; Wahab, A. E. A and Metwally, A. M., 1974. Soil arthropods (other than insects) in a newly reclaimed area in Nasr city. Bull. Soc. Ent. Egypt, LVII: 271-284.

Hassan, M. F.; Afifi. A. M. and Nawar, M. S., 1986. Mites inhabiting plants and soil in Sinai and newly reclaimed land. Bull.Soc.Ent.Egypt,66: 211-225.

Hansen, R. A. and Coleman, D. C., 1998. Litter complexity and composition are determination of the diversity and species of oribatid mites (Acari : Oribatida ) in litter bags. Applied Soil Ecology, 9: 17-23.

Kandeel, M. M. H., 1993. Annotated lest and keys to mites occurring in North Sinai, Egypt. J. Product. \& Dev. I (1): 55-80.

Kang, B.; Lee, J. H. and Choi, S.S., 2001. Soil oribatid mite (Acari) settling in the forest litter in the different microenvironments in MT. Jumbong, Korea. Korean, J. Ecol., 24 (4): 233237.

Karg, w., 1971. Acari (Acarina), Milben Unterodnung Anactinochaeta (Parasitiformes). Veb Gustav Fischer Verlag Jean. 457pp.

Koehler, H., 1997. Mesostigmata (Gamasina, Uropodina), efficient predators in agroecosystems. Agriculture, Ecosystems and Environ, 62: 105-117.

Koehler, H., 1999. Predatory mites (Gamasina,
Mesostigmata). Agric. Ecosys. Environ., 74: 395-410.

Magurran, A. E., 1988. Ecological diversity and its measurements. Croom Helm. London, UK. $179 \mathrm{pp}$.

Parisi, V.; Menta, C.; Gardi, C.; Jacomini, C. and Mozzanica, E., 2005. Microarthropod communities as a tool to assess soil quality and biodiversity: a new approach in Italy. Agric Ecosys. Env., 105:323-333.

Ruf, A. and Beck, L., 2005. The use of predatory soil mites in ecological soil classification and assessment concepts, with perspectives for oribatid mites. Ecotox. Environ. Safety, 62: 290-299.

Schneider, K.; Scheu, S. and Maraun M., 2007. Microarthropod density and diversity respond little to spatial isolation. Basic Appl. Ecol, 8: 26-35.

Seastedt, T. R., 1984. The role of microarthropods in decomposition and mineralization processes. Annual Review of Entomology, 29:25-46.

Usher, M.B., 1971. Seasonal and vertical distribution of population of soil arthropods: Mesostigmata. Pedobiologia, 11: 27-39.

Zaher, M. A., 1986. Survey and ecological studies of phytophagous, predaceous and soil mites in Egypt. Final report PL 480, Programme USA Project No. EG. ARS-30, grant No.FG-139. Fac. of Agric., Cairo Univ.

Zaher, M. A. and Mohamed, M. I., 1980. Soil mites associated with some crops in Sinai Peninsula. Ann. of Agric. Sc., Moshtohor, 13: 209-214.

Zaki, A. M., 1992. Population dynamics of soil mites associated with some stone fruit trees in Menoufia, Egypt. Acta Phytopathologica et Entomologica Hungarica, 27 (1-4): 679-685. 